UDC $575.1+577.11+577.21$

\title{
Association of the EPHA1 gene polymorphism with idiopathic mild intellectual disability
}

\author{
R. V. Gulkovskyi ${ }^{1,2}$, A.V. Sivolob ${ }^{2}$, L. A. Livshits ${ }^{1,2}$ \\ ${ }^{1}$ Institute of Molecular Biology and Genetics, NAS of Ukraine \\ 150, Akademika Zabolotnoho Str., Kyiv, Ukraine, 03680 \\ 2 Educational and Scientific Center "Institute of Biology", \\ Taras Shevchenko National University of Kyiv \\ 64/13, Volodymyrska Str., Kyiv, Ukraine, 01601 \\ livshits@imbg.org.ua
}

\begin{abstract}
Aim. To investigate a possible association of the EPHA1 gene polymorphism with mild intellectual disability (ID). Methods. The group of patients with mild (IQ score between 50 and 70) idiopathic intellectual disability consisted of 65 individuals including $41(63.1 \%)$ males and $24(36.9 \%)$ females. The control group consisted of 250 healthy volunteers from different regions of Ukraine. The genotyping was performed using PCR followed by RFLP analysis for rs 11768549 , rs11767557, rs11771145 and ARMS PCR analysis for novel c.1891G $>$ A EPHA1 gene mutation. Results. The data concerning the EPHA1 genotypes and allelic variants distribution in ID patients and control group were obtained. Statistical analysis showed a significant association of minor rs $11768549-\mathrm{A}$ allele $(\mathrm{OR}=3.96,95 \% \mathrm{CI}=1.13-13.89)$ and wild-type rs $11767557-\mathrm{T}(\mathrm{OR}=1.99,95 \% \mathrm{CI}=1.18-3.37)$ and $\mathrm{rs} 11771145-\mathrm{G}(\mathrm{OR}=1.55,95 \% \mathrm{CI}=1.02-2.37)$ alleles with a higher risk of mild ID development ( $p<0.05$ for all). Conclusions. Our results suggest that SNPs (rs11768549, rs11767557, rs11771145) in the EPHA1 gene are associated with idiopathic mild intellectual disability. Therefore, we propose the EPHA1gene as a new candidate gene and the polymorphisms rs11768549, rs11767557, rs11771145 as new markers of genetic susceptibility for intellectual disability.
\end{abstract}

Keywords: EPHA1 gene, intellectual disability, polymorphism, genetic susceptibility.

\section{Introduction}

In recent reports we have presented our study on the whole exome sequencing (WES) in two affected siblings with non-syndromic intellectual disability from Ukrainian family and their healthy non-consanguineous parents that identified two missense mutations in the coding region of the EPHA1 gene (c. $1475 \mathrm{G}>$ A - rs11768549 and novel c.1891G > A) [1-3].

The EPHA1 gene is located at chromosome $7 \mathrm{q} 34$ and contains 18 exons that span a little over $18 \mathrm{~kb}$ [4]. The human EPHA1 gene is transcribed as a single $3.5 \mathrm{~kb}$ mRNA [5]. The EPHA1 protein contains 976 amino acids and is approximately 108
$\mathrm{kDa}$ [6]. EPHA1 is the first identified member of the erythropoietin-producing hepatocellular (Eph) receptors family [7]. EPHA1 is a receptor tyrosine kinase that plays an important role in developmental processes, including nervous system, where it participates in the forward signaling in receptorbearing cells and the reverse signaling in ligandbearing cells by binding to GPI-linked A ephrins, which together facilitate communication between neighboring cell populations and axon guidance $[6,8-12]$. Ephrin type-A receptor 1 is highly expressed in the adult brain and in the spinal neural tube during neurulation $[13,14]$ and seems to be a good disease gene in ID.

(C) 2015 R. V. Gulkovskyi et al.; Published by the Institute of Molecular Biology and Genetics, NAS of Ukraine on behalf of Biopolymers and Cell. This is an Open Access article distributed under the terms of the Creative Commons Attribution License (http://creativecommons.org/licenses/by/4.0/), which permits unrestricted reuse, distribution, and reproduction in any medium, provided the original work is properly cited 
The previous studies have shown that EPHA1 regulates the cell morphology and motility through the ILK-RhoA-ROCK pathway [15]. It is therefore important to note that mutations in the genes encoding the regulators and effectors of the Rho GTPases such as OPHN1, PAK3, alpha-PIX (also known as ARHGEF6 or Cool-2), FMR1 and MEGAP have been found to underlie various forms of ID $[16,17]$. Interestingly, the defects in Rho signaling pathways have recently also been linked with Alzheimer disease (AD) as well as the EPHA1 gene SNPs [18, 19]. EPHA1 was documented to be one of the most strongly associated locus with $\mathrm{AD}$ in a few recent genome wide association studies [20-22]. It was shown that the minor $\mathrm{C}$ allele at SNP rs11767557 of EPHA1 was associated with significantly lower odds of being $A \beta$-positive and protective for late onset $\mathrm{AD}$ (LOAD) as well as having the minor A allele in another SNP rs11771145 on EPHA1 was also associated with lower odds of AD [20-22]. Furthermore, the EPHA1 gene SNP rs11768549 was associated with the rapid $\mathrm{AD}$ progression and the missense mutations in the coding region of the EPHA1 gene rs202178565 - with LOAD [23, 24].

Intellectual disability is a common neurodevelopmental disorder occurring in 1-3\% of the general population and its burden on the affected individuals, their families and society is enormous. [25]. Still, in $\sim 60 \%$ of cases of ID the etiology is unknown because of the extensive clinical and genetic heterogeneity [26]. The causes of intellectual disability vary with the severity of the condition: moderate-tosevere intellectual disability (IQ less than 50) is much more likely to be due to a single pathological cause (genetic or environmental) whereas mild ID (defined as an IQ score between 50 and 70) is rather a complex condition in origin as well as AD [27].

The aim of this study is to evaluate a possible association of the EPHA1 gene polymorphisms rs11768549, rs11767557, rs11771145 and novel c. $1891 \mathrm{G}>\mathrm{A}$ mutation with mild intellectual disability.

\section{Materials and Methods}

DNA-samples were extracted from peripheral blood leucocytes of unrelated volunteers from different regions of Ukraine and ID patients by the standard phenol-chloroform method. Informed consents were obtained from all the individuals participating in our study.

The group of patients with mild (an IQ score between 50 and 70) idiopathic intellectual disability consisted of 65 individuals including 41 (63.1\%) males and $24(36.9 \%)$ females, where the previous extensive genetic investigations revealed no abnormalities. All patients underwent physical and neurological examination (test used for IQ: WISC III, WISC-R, WISC) and standard G-banding karyotype analysis. DNA tests to determine Fragile $X$ status (FRAXA, FRAXE, FRAXF loci) and Prader Willi/Angelman syndromes (PW/AS) were performed to rule out the known genetic causes of ID prior to further investigation. Array-CGH analysis (400K resolution) revealed no pathological rearrangements in all patients.

The control group consisted of 250 individuals including 131 (52.4\%) males and 119 (47.6 \%) females. This group may be considered representative for the estimation of DNA polymorphism frequency in autosomal genes [28].

Polymorphic variants c.1475G > A (rs11768549) and c. $1891 \mathrm{G}>\mathrm{A}$ (novel) of EPHA1 gene were detected as described in our recent work [2].

The presence of EPHA1 polymorphism rs11767557 was examined by RsaI PCR-RFLP (restriction fragment length polymorphism) analysis. Specific oligonucleotides, designed and synthesized in accordance to corresponding sequences of EPHA1 gene that were used as primers are presented in Table 1 . The PCR amplification was performed in a final volume of $25 \mu$ containing $1 \times$ PCR buffer, $1.5 \mathrm{mM} \mathrm{MgCl}$, $200 \mu \mathrm{M}$ of each dNTP, $1 \mu \mathrm{M}$ of each primer, 0.2 units of Taq-DNA polymerase and $200 \mathrm{ng}$ of the DNA template. The cycling conditions were as follows: initial denaturation at $95{ }^{\circ} \mathrm{C}$ for $5 \mathrm{~min}, 30 \mathrm{cy}-$ cles consisting of denaturation at $94{ }^{\circ} \mathrm{C}$ for $30 \mathrm{~s}$, annealing at $63{ }^{\circ} \mathrm{C}$ for $30 \mathrm{~s}$, extension at $72{ }^{\circ} \mathrm{C}$ for $30 \mathrm{~s}$ and a final elongation step at $72{ }^{\circ} \mathrm{C}$ for $3 \mathrm{~min}$. The amplified fragments were digested with RsaI. Digestion was performed in $15 \mu \mathrm{l}$ reaction volume containing $1 \mathrm{X}$ reaction buffer, 0.5 units of the restriction enzyme and $10 \mu \mathrm{l}$ of purified PCR product, in- 


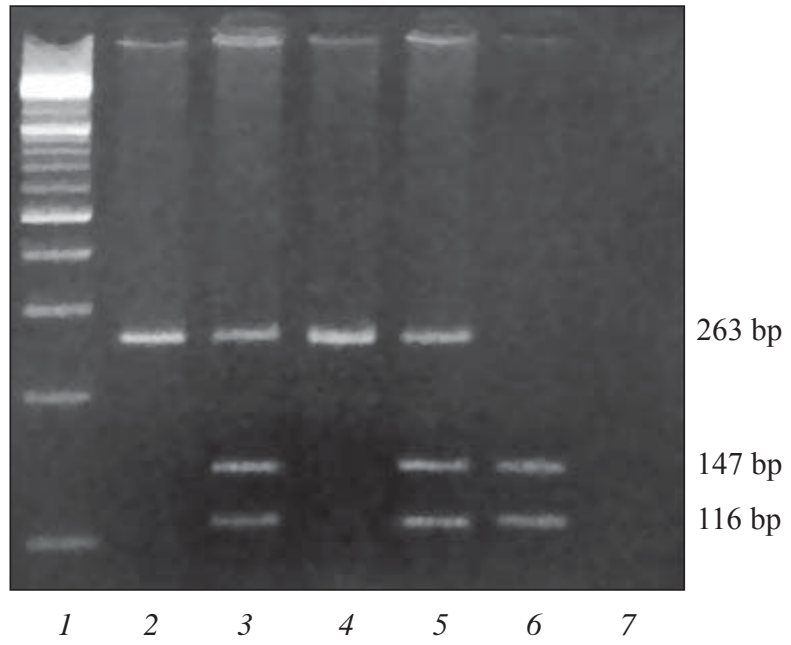

Fig. 1. RFLP analysis of rs11767557 EPHA1 receptor gene variant (2\% agarose gel electrophoresis): 1 - molecular mass marker (Ladder $100 \mathrm{bp}$ ); 2, 4 - individuals with homozygous genotype TT; 3, 5 - individuals with heterozygous genotype TC; 6 individual with homozygous genotype $\mathrm{CC}, 7$-negative control

cubated at $37{ }^{\circ} \mathrm{C}$ overnight and analyzed using $2 \%$ standard agarose gelelectrophoreses.

The assessment of the EPHA1 rs11771145 polymorphism was performed by the DraI PCR-RFLP analysis using the specific oligonucleotide primers described in Table 1. In the forward primer, the mismatched nucleotides (underlined) were substituted so that amplification of the minor A-allele resulted in the generation of a new DraI restriction cutting site. The PCR amplification was performed in a final volume of $25 \mu$ containing $1 \times$ PCR buffer, $1.5 \mathrm{mM} \mathrm{MgCl} 2,200$ $\mu \mathrm{M}$ of each dNTP, $1 \mu \mathrm{M}$ of each primer, 0.2 units of Taq-DNA polymerase and $200 \mathrm{ng}$ of the DNA template. The cycling conditions were as follows: initial denaturation at $95{ }^{\circ} \mathrm{C}$ for $5 \mathrm{~min}, 30$ cycles consisting of denaturation at $94{ }^{\circ} \mathrm{C}$ for $30 \mathrm{~s}$, annealing at $58^{\circ} \mathrm{C}$ for $30 \mathrm{~s}$, extension at $72^{\circ} \mathrm{C}$ for $30 \mathrm{~s}$ and a final elonga- tion step at $72{ }^{\circ} \mathrm{C}$ for $3 \mathrm{~min}$. The amplified fragments were digested with DraI. Digestion was performed in $15 \mu \mathrm{l}$ reaction volume containing $1 \mathrm{X}$ reaction buffer, 0.5 units of the restriction enzyme and $10 \mu \mathrm{l}$ of purified PCR product, incubated at $37{ }^{\circ} \mathrm{C}$ overnight and analyzed in $2 \%$ standard agarose gels.

The primers were designed using a web-based PRIMER 3.0 program (http://workbench.sdsc.edu). We used the «BLAST» program at http://www.ncbi. nlm.nih.gov/blast to check for the specificity of the primers. Hypothetical RFLP results were tested using NEBcutter V2.0 (http://tools.neb.com/NEBcutter2).

The results were statistically assessed using Arlequin and OpenEpi software and Fisher's 2 by 2 exact test, as well as odd ratio (OR) calculation; $\mathrm{p}<0.05$ was considered to be statistically significant test $[29,30]$.

\section{Results and Discussion}

We did not identify c.1891G>A (p.Gly631Arg) substitution in any of the investigated individuals from the ID patients $(n=65)$ and control groups $(n=250)$. It was found only in the members of aforesaid Ukrainian family with ID in two siblings. Furthermore, c.1891G $>$ A substitution was not observed in any of Exome Aggregation Consortium (URL: http://exac.broadinstitute.org), International HapMap Project (URL: http://hapmap. ncbi.nlm.nih.gov/) and 1000 Genomes Project (URL: http://browser.1000genomes.org/) populations. Therefore, we assume that the EPHA1 gene c. $1891 \mathrm{G}>\mathrm{A}$ (p.Gly631Arg) is the mutation with an extremely low frequency.

Based on the RFLP analysis of rs11768549 (c. $1475 \mathrm{G}>\mathrm{A}$ and $\mathrm{p}$. Arg 492Gln) variant, the individuals were classified into three groups: GG, GA and AA. The genotypes and allele frequencies of the rs11768549 polymorphism are presented in Table 2 .

Table 1. Sequences of PCR-RFLP primers used in genotyping reactions

\begin{tabular}{|c|l|c|}
\hline Substitution & \multicolumn{1}{|c|}{ Nucleotide sequence } & Amplicon size, bp \\
\hline rs11767557 T $>$ C & GGGTCTTTCTCTTTAGTATGATGCTCC - forward & 263 \\
& CAGACGCCAGAAGGGGAAAGA - reverse & 122 \\
rs11771145 G $>$ A & TGGATTTGCCTGTTCTTAAACTTTTT - forward & \\
& CTGAATCCACACACAACCAAGGAA - reverse & \\
\hline
\end{tabular}


The $\mathrm{T}$ to $\mathrm{C}$ transition in the rs 11767557 variant, located in EPHA1-AS1 (EPHA1 antisense RNA 1), generates a restriction site for endonuclease RsaI. Thereby three different patterns could be observed after the restriction digestion of the PCR-product: a 263 bp band (for genotype TT); a $263 \mathrm{bp}$, a $147 \mathrm{bp}$ and a $116 \mathrm{bp}$ bands (for genotype TC); a $147 \mathrm{bp}$ and a 116 bp bands (for genotype CC) (Fig. 1).

In the forward primer, designed for the rs 117 71145 (located in EPHA1-AS1) analysis, the mismatched nucleotides (underlined) were substituted so that amplification of the minor A-allele resulted in the generation of a new DraI restriction cutting site. Thereby three different patterns could be observed after the restriction digestion: a $122 \mathrm{bp}$ band (for GG genotype); a 122 bp, a 96 bp and a 26 bp (not visible on electrophoregram) bands (for GA genotype); a 96 bp and a 26 bp bands (for AA genotype) (Fig. 2). The genotype and allele frequencies of the rs11767557 and rs11771145 polymorphisms are summarized in Table 2.

All observed genotype distributions showed no deviations from Hardy-Weinberg expectations in the general population of Ukraine and in the ID patients group ( $p>0.05)$. A significant linkage disequilibrium (LD) was found between rs11768549 and $\mathrm{rs} 11767557(\mathrm{p}=0.00436), \mathrm{rs} 11767557$ and rs11771145 $(\mathrm{p}<0.0001)$.

The SNP analysis showed the significant differences between the ID patients and the controls for the allele frequencies of all (rs11768549, rs11767557,rs11771145) investigated SNPs ( $p<0.05$ for all). We found a signifacant association of minor rs11768549-A (OR = $3.96,95 \% \mathrm{CI}=1.13-13.89)$ and wild-type rs11767557-T $(\mathrm{OR}=1.99,95 \% \mathrm{CI}=1.18-3.37)$ and rs11771145-G $(\mathrm{OR}=1.55,95 \% \mathrm{CI}=1.02-2.37)$ alleles with a higher risk of mild ID development. Three studied polymorphic variants showed a significant association with mild ID for different genetic models: multiplicative for rs11768549 (A vs G: $\mathrm{OR}=3.96,95 \% \mathrm{CI}=1.13-13.89, \mathrm{p}=0.02)$, recessive for rs11767557 (TT vs TC + CC: OR $=0.50$, $95 \% \mathrm{CI}=0.27-0.9, \mathrm{p}=0.02)$ and dominant for rs11771145 (GG+AG vs AA: $\mathrm{OR}=0.28,95 \% \mathrm{CI}=$ $=0.08-0.93, p=0.03)$. Genotypes rs11767557-

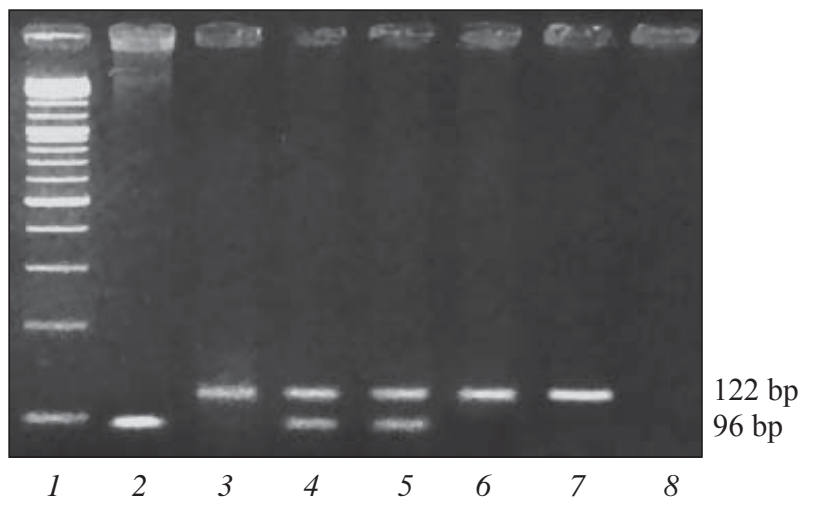

Fig. 2. RFLP analysis of rs11771145 EPHA1 receptor gene variant ( $2 \%$ agarose gel electrophoresis): 1 - molecular mass marker (Ladder $100 \mathrm{bp}$ ); 2 - individual with homozygous genotype AA; 3, 6, 7 - individuals with heterozygous genotype GA; 4, 5 individuals with homozygous genotype $\mathrm{GG}, 8$ - negative control

Table 2. Distribution of genotypes

and allele variants in investigated groups

\begin{tabular}{|c|c|c|}
\hline & Control group, $n=250$ & ID patients, $n=65$ \\
\hline \multicolumn{3}{|c|}{ rs11768549 G>A } \\
\hline \multicolumn{3}{|c|}{ Genotype, $n(\%)$} \\
\hline GG & $245(98)$ & $60(92.3)$ \\
\hline GA & $5(2)$ & $5(7.7)$ \\
\hline AA & 0 & 0 \\
\hline \multicolumn{3}{|c|}{ Allele,n (frequency) } \\
\hline $\mathrm{G}$ & $125(0.99)$ & $495(0.962)$ \\
\hline A & $5(0.01)$ & $5(0.038)^{*}$ \\
\hline \multicolumn{3}{|c|}{ rs $11767557 \mathrm{~T}>\mathrm{C}$} \\
\hline \multicolumn{3}{|c|}{ Genotype, $n(\%)$} \\
\hline TT & $141(56.4)$ & 47 (72.3) \\
\hline $\mathrm{TC}$ & $91(36.4)$ & $17(26.2)$ \\
\hline $\mathrm{CC}$ & $18(7.2)$ & $1(1.5)$ \\
\hline $\mathrm{TC}+\mathrm{CC}$ & $109(43.6)$ & $18(27.7)^{*}$ \\
\hline \multicolumn{3}{|c|}{ Allele,n (frequency) } \\
\hline $\mathrm{T}$ & $373(0.746)$ & $111(0.854)$ \\
\hline $\mathrm{C}$ & $127(0.254)$ & $19(0.146)^{*}$ \\
\hline \multicolumn{3}{|c|}{ rs11771145 G>A } \\
\hline \multicolumn{3}{|c|}{ Genotype, $n(\%)$} \\
\hline GG & $96(38.4)$ & $31(47.7)$ \\
\hline GA & 117 (46.8) & 31 (47.7) \\
\hline AA & $37(14.8)$ & $3(4.6)^{*}$ \\
\hline $\mathrm{GG}+\mathrm{AG}$ & $213(85.2)$ & $62(95.4)^{*}$ \\
\hline \multicolumn{3}{|c|}{ Allele,n (frequency) } \\
\hline $\mathrm{G}$ & $309(0.618)$ & $93(0.715)$ \\
\hline A & $191(0.382)$ & $37(0.285)^{*}$ \\
\hline
\end{tabular}

Notes. $\mathrm{n}$ - number of individuals; *statistically reliable difference $(p<0.05)$. 
$\mathrm{TC}+\mathrm{CC}$ and rs11771145-AA were associated with significantly lower odds of mild ID developing.

The non-synonymous SNP rs11768549 is located in the coding region (exons 7) of the EPHA1 receptor gene and results in the mutation of a positive charged Arg492 to an uncharged Gln492 located in the fibronectin type III repeat of the EphA1 ectodomain. This mutation may directly cause the changes in the domain conformational flexibility and might result in the decrease of signal transduction and binding with the ligands or the protein-partners. The SNPs rs11767557 and rs11771145 are located in the EPHA1 antisense RNA 1 (long non-coding RNA), near the promoter region and may affect the regulation of the EPHA1 gene expression. Long non-coding RNAs have emerged as key regulators of the gene expression at different levels, including chromatin remodeling, transcriptional control, mRNA stability, mRNA translation, microRNA function, and protein metabolism [31,32]. Our results suggest that SNPs (rs11768549, rs11767557, rs11771145) in the EPHA1 gene are associated with idiopathic mild ID. These data can be explained by the changes in the EPHA1 receptor signal transduction efficiency in the rs11768549 minor allele A carriers and/or in the EPHA1 gene expression levels in individuals with different rs11767557 and rs11771145 genotypes that in turn, may affect the regulation of neurogenesis, axon guidance and synaptic plasticity at least via the EPHA1-ILK-RhoA-ROCK signaling.

Therefore, we propose EPHA1 as a new candidate gene and the polymorphisms (rs11768549, rs11767557, rs11771145) as new markers of the genetic susceptibility for intellectual disability. Further investigations are necessary to explain the molecular mechanisms of the EPHA1 involvement in ID pathogenesis.

\section{Acknowledgements}

We thank the patients and volunteers for their cooperation.

\section{REFERENCES}

1. Gulkovskyi RV, Chernushyn SY, Kravchenko SA, Bychkova GM, Livshits LA. EPHA1 gene SNPs analysis in population of Ukraine. Biopolym Cell. 2013;29(6):506-10.
2. Gulkovskyi RV, Chernushyn SY, Livshits LA. Novel gene PUS3 c.A212G mutation in Ukrainian family with intellectual disability. Biopolym Cell. 2015;31(2):123-30.

3. Gulkovskyi RV, Chernushyn SY, Kravchenko SA, Livshits LA. ZNF527 GENE rs386809049 Analysis in population of Ukraine. Tsitol Genet. 2015;49(4):35-9.

4. Owshalimpur D, Kelley MJ. Genomic structure of the EPHA1 receptor tyrosine kinase gene. Mol Cell Probes. 1999;13(3):169-73.

5. Maru Y, Hirai H, Takaku F. Overexpression confers an oncogenic potential upon the eph gene. Oncogene. 1990;5 (3):445-7.

6. Kullander K, Klein R. Mechanisms and functions of Eph and ephrin signalling. Nat Rev Mol Cell Biol. 2002;3(7):47586.

7. Hirai H, Maru Y, Hagiwara K, Nishida J, Takaku F. A novel putative tyrosine kinase receptor encoded by the eph gene. Science. 1987;238(4834):1717-20.

8. Himanen JP, Nikolov DB. Eph receptors and ephrins. Int $J$ Biochem Cell Biol. 2003;35(2):130-4.

9. Pasquale EB. Eph receptor signalling casts a wide net on cell behaviour. Nat Rev Mol Cell Biol. 2005;6(6):462-75.

10. Wilkinson DG. Eph receptors and ephrins: regulators of guidance and assembly. Int Rev Cytol. 2000;196:177-244.

11. Poliakov A, Cotrina M, Wilkinson DG. Diverse roles of eph receptors and ephrins in the regulation of cell migration and tissue assembly. Dev Cell. 2004;7(4):465-80.

12. Noren NK, Pasquale EB. Eph receptor-ephrin bidirectional signals that target Ras and Rho proteins. Cell Signal. 2004; 16(6):655-66.

13. Abdul-Aziz NM, Turmaine M, Greene ND, Copp AJ. Ephri$n A-E p h A$ receptor interactions in mouse spinal neurulation: implications for neural fold fusion. Int J Dev Biol. 2009;53 (4):559-68.

14. Karch CM, Jeng AT, Nowotny P, Cady J, Cruchaga C, Goate $A M$. Expression of novel Alzheimer's disease risk genes in control and Alzheimer's disease brains. PLoS One. 2012;7 (11):e50976.

15. Yamazaki T, Masuda J, Omori T, Usui R, Akiyama H, Maru $Y$. EphA1 interacts with integrin-linked kinase and regulates cell morphology and motility. J Cell Sci. 2009;122(Pt 2): 243-55.

16. Nadif Kasri N, Van Aelst L. Rho-linked genes and neurological disorders. Pflugers Arch. 2008;455(5):787-97.

17. Newey SE, Velamoor V, Govek EE, Van Aelst L. Rho GTPases, dendritic structure, and mental retardation. J Neurobiol. 2005;64(1):58-74.

18. Zhao L, Ma QL, Calon F, Harris-White ME, Yang F, Lim GP, Morihara T, Ubeda OJ, Ambegaokar S, Hansen JE, Weisbart RH, Teter B, Frautschy SA, Cole GM. Role of p21activated kinase pathway defects in the cognitive deficits of Alzheimer disease. Nat Neurosci. 2006 ;9(2):234-42.

19. Ma QL, Yang F, Calon F, Ubeda OJ, Hansen JE, Weisbart $R H$, Beech W, Frautschy SA, Cole GM. p21-activated ki- 
Association of the EPHA1 gene polymorphism with idiopathic mild intellectual disability

nase-aberrant activation and translocation in Alzheimer disease pathogenesis. J Biol Chem. 2008;283(20):14132-43.

20. Seshadri S, Fitzpatrick AL, Ikram MA, DeStefano AL, Gudnason V, Boada M, Bis JC, Smith AV, Carassquillo MM, Lambert JC, Harold D, Schrijvers EM, Ramirez-Lorca R, Debette S, Longstreth WT Jr, Janssens AC, Pankratz VS, Dartigues JF, Hollingworth P, Aspelund T, Hernandez I, Beiser A, Kuller LH, Koudstaal PJ, Dickson DW, Tzourio C, Abraham R, Antunez C, Du Y, Rotter JI, Aulchenko YS, Harris TB, Petersen RC, Berr C, Owen MJ, Lopez-Arrieta J, Varadarajan BN, Becker JT, Rivadeneira F, Nalls MA, Graff-Radford NR, Campion D, Auerbach S, Rice K, Hofman A, Jonsson PV, Schmidt H, Lathrop M, Mosley TH, Au $R$, Psaty BM, Uitterlinden AG, Farrer LA, Lumley T, Ruiz A, Williams J, Amouyel P, Younkin SG, Wolf PA, Launer LJ, Lopez OL, van Duijn CM, Breteler MM; CHARGE Consortium; GERAD1 Consortium; EADI1 Consortium. Genomewide analysis of genetic loci associated with Alzheimer disease. JAMA. 2010;303(18):1832-40.

21. Naj AC, Jun G, Beecham GW, Wang LS, Vardarajan BN, Buros $J$, et al. Common variants at MS4A4/MS4A6E, CD2AP, CD33 and EPHA1 are associated with late-onset Alzheimer's disease. Nat Genet. 2011;43(5):436-41.

22. Hollingworth P, Harold D, Sims R, Gerrish A, Lambert JC, Carrasquillo $M M$, et al. Common variants at ABCA7, MS4 A6A/MS4A4E, EPHA1, CD33 and CD2AP are associated with Alzheimer's disease. Nat Genet. 2011;43(5):429-35.

23. Wang X, Lopez OL, Sweet RA, Becker JT, DeKosky ST, Barmada MM, Demirci FY, Kamboh MI. Genetic determinants of disease progression in Alzheimer's disease. J Alzheimers Dis. 2015;43(2):649-55.

24. Vardarajan BN, Ghani M, Kahn A, Sheikh S, Sato C, Barral $S$, Lee JH, Cheng R, Reitz C, Lantigua R, Reyes-Dumeyer D, Medrano M, Jimenez-Velazquez IZ, Rogaeva E, St GeorgeHyslop P, Mayeux $R$. Rare coding mutations identified by sequencing of Alzheimer disease genome-wide association studies loci. Ann Neurol. 2015;78(3):487--98.

25. Leonard $H$, Wen $X$. The epidemiology of mental retardation: challenges and opportunities in the new millennium. Ment Retard Dev Disabil Res Rev. 2002;8(3):117-34.

26. Rauch A, Hoyer J, Guth S, Zweier C, Kraus C, Becker C, Zenker M, Hüffmeier U, Thiel C, Rüschendorf F, Nürnberg $P$, Reis A, Trautmann U. Diagnostic yield of various genetic approaches in patients with unexplained developmental delay or mental retardation. Am J Med Genet A. 2006;140(19): 2063-74.

27. Flint J. Genetic basis of cognitive disability. Dialogues Clin Neurosci. 2001;3(1):37-46.
28. Balding DJ. A tutorial on statistical methods for population association studies. Nat Rev Genet. 2006;7(10):781-91.

29. Sullivan KM, Dean A, Soe MM. OpenEpi: a web-based epidemiologic and statistical calculator for public health. Public Health Rep. 2009;124(3):471-4.

30. Excoffier L, Laval G, Schneider S. Arlequin (version 3.0): an integrated software package for population genetics data analysis. Evol Bioinform Online. 2007;1:47-50.

31. Yang L, Lin C, Jin C, Yang JC, Tanasa B, Li W, Merkurjev $D$, Ohgi KA, Meng D, Zhang J, Evans CP, Rosenfeld MG. lncRNA-dependent mechanisms of androgen-receptor-regulated gene activation programs. Nature. 2013;500(7464): 598-602.

32. Yoon JH, Abdelmohsen K, Gorospe M. Posttranscriptional gene regulation by long noncoding RNA. J Mol Biol. 2013; 425(19):3723-30.

\section{Асоціація поліморфізму гена ЕРНА1 з ідіопатичною легкою інтелектуальною недісздатністю}

Р. В. Гулковський, А. В. Сиволоб, Л. А. Лівшиць

Мета. Дослідити можливу асоціацію поліморфізму гена EPHA1 з легкою інтелектуальною недієздатністю (IH). Методи. Група пацієнтів $з$ легкою (IQ між 50 і 70) ідіопатичною інтелектуальною недієздатністю складалася з 65 індивідів, включаючи 41 (63.1 \%) чоловіка і 24 (36.9 \%) жінки. Контрольна група складалася з 250 здорових добровольців 3 різних регіонів України. Генотипування проводили за допомогою ПЛР з подальшим ПДРФ аналізом для rs11768549, rs11767557, rs11771145 та алель-специфічної ПЛР для нової с.1891G>A мутації в гені ЕРНА1. Результати. Отримані дані про розподіл генотипів і алельних варіантів гена EPHA1 в групі пацієнтів з IH і в контрольній групі. За результатами статистичного аналізу встановлено достовірну асоціацію мінорного rs117685 49- А алеля $(\mathrm{OR}=3.96,95 \%$ $\mathrm{CI}=1.13$ - 13.89) і алелів дикого типу rs $11767557-\mathrm{T}(\mathrm{OR}=$ $1.99,95 \% \mathrm{CI}=1.18-3.37)$ та $\mathrm{rs} 11771145-\mathrm{G}(\mathrm{OR}=1.55,95 \%$ $\mathrm{CI}=1.02-2.37)$ з більш високим ризиком розвитку легкої IH ( $>0,05$ для всіх). Висновки. Наші результати показують, що SNPs (rs11768549, rs11767557, rs11771145) в гені EPHА1 асоційовані $з$ легкою ідіопатичною інтелектуальною недієздатністю. Тому ми пропонуємо ЕРНА1 як новий кандидатний ген, а поліморфізми rs11768549, rs11767557, rs11771145 - як нові маркери генетичної схильності до інтелектуальної недієздатності.

Кл юч о в і с л о в а: ген EPHA1, інтелектуальна недієздатність, поліморфізм, генетична схильність 


\section{Ассоциация полиморфизма гена ЕРНА1 с идиопатической легкой интеллектуальной недееспособностью}

\author{
Р. В. Гулковский, А. В. Сиволоб, Л. А. Лившиц
}

Цель. Исследовать возможную ассоциацию полиморфизма гена ЕPHA1 с легкой интеллектуальной недееспособностью (ИН). Методы. Группа пациентов с легкой (IQ между 50 и 70) идиопатической интеллектуальной недееспособностью состояла из 65 индивидов, включая 41 (63.1 \%) мужчину и 24 (36.9 \%) женщины. Контрольная группа состояла из 250 здоровых добровольцев из разных регионов Украины. Генотипирование проводили посредством ПЦР с последующим ПДРФ анализом для rs11768549, rs 11767557 , rs11771145 и аллель- специфической ПЦР для новой с.18 91G>A мутации в гене ЕРНА1. Результаты. Были получены данные о распределении генотипов и аллельных вариантов гена EPHA1 в группе пациентов с ИН и в контроль- ной группе. Статистический анализ показывает достоверную ассоциацию минорного rs11768549-А аллеля $(\mathrm{OR}=3.96$, $95 \% \mathrm{CI}=1.13-13.89)$ и аллелей дикого типа rs11767557-T $(\mathrm{OR}=1.99,95 \% \mathrm{CI}=1.18-3.37)$ и $\mathrm{rs} 11771145-\mathrm{G}(\mathrm{OR}=1.55$, $95 \% \mathrm{CI}=1.02-2.37)$ с более высоким риском развития легкой ИН ( $<<0,05$ для всех). Выводы. Наши результаты показывают, что SNPs (rs11768549, rs11767557, rs11771145) в гене ЕРНА1 ассоциированы с легкой идиопатической интеллектуальной недееспособностью. Поэтому мы предлагаем EPHA1 в качестве нового гена кандидата и полиморфизмы rs11768549, rs11767557, rs11771145 в качестве новых маркеров генетической предрасположенности к интеллектуальной недееспособности.

К л юч е в ы е с л о в а: ген EPHA1, интеллектуальная недееспособность, полиморфизм, генетическая предрасположенность.

Received 23.05.2015 